This is an electronic reprint of the original article. This reprint may differ from the original in pagination and typographic detail.

Author(s): Kilpi, Laura; Ylivaara, Oili M. E.; Vaajoki, Antti; Liu, Xuwen; Rontu, Ville; Sintonen, Sakari; Haimi, Eero; Malm, Jari; Bosund, Markus; Tuominen, Marko; Sajavaara, Timo; Lipsanen, Harri; Hannula, Simo-Pekka; Puurunen, Riikka L.; Ronkainen, Helena

Title: $\quad$ Tribological properties of thin films made by atomic layer deposition sliding against silicon

Year: $\quad 2018$

Version:

Please cite the original version:

Kilpi, L., Ylivaara, O. M. E., Vaajoki, A., Liu, X., Rontu, V., Sintonen, S., Haimi, E., Malm, J., Bosund, M., Tuominen, M., Sajavaara, T., Lipsanen, H., Hannula, S.-P., Puurunen, R. L., \& Ronkainen, H. (2018). Tribological properties of thin films made by atomic layer deposition sliding against silicon. Journal of Vacuum Science and Technology A, 36(1), Article 01A122. https://doi.org/10.1116/1.5003729

All material supplied via JYX is protected by copyright and other intellectual property rights, and duplication or sale of all or part of any of the repository collections is not permitted, except that material may be duplicated by you for your research use or educational purposes in electronic or print form. You must obtain permission for any other use. Electronic or print copies may not be offered, whether for sale or otherwise to anyone who is not an authorised user. 


\section{Tribological properties of thin films made by atomic layer deposition sliding against silicon}

Lauri Kilpi, Oili M. E. Ylivaara, Antti Vaajoki, Xuwen Liu, Ville Rontu, Sakari Sintonen, Eero Haimi, Jari Malm, Markus Bosund, Marko Tuominen, Timo Sajavaara, Harri Lipsanen, Simo-Pekka Hannula, Riikka L. Puurunen, and Helena Ronkainen

Citation: Journal of Vacuum Science \& Technology A: Vacuum, Surfaces, and Films 36, 01A122 (2018);

View online: https://doi.org/10.1116/1.5003729

View Table of Contents: http://avs.scitation.org/toc/jva/36/1

Published by the American Vacuum Society

\section{Articles you may be interested in}

Atomic layer deposition of molybdenum disulfide films using $\mathrm{MoF}_{6}$ and $\mathrm{H}_{2} \mathrm{~S}$

Journal of Vacuum Science \& Technology A: Vacuum, Surfaces, and Films 36, 01 A125 (2017);

$10.1116 / 1.5003423$

Review Article: Recommended reading list of early publications on atomic layer deposition-Outcome of the "Virtual Project on the History of ALD"

Journal of Vacuum Science \& Technology A: Vacuum, Surfaces, and Films 35, 010801 (2016);

$10.1116 / 1.4971389$

Plasma-enhanced atomic layer deposition of nickel thin film using bis(1,4-diisopropyl-1,4-diazabutadiene)nickel Journal of Vacuum Science \& Technology A: Vacuum, Surfaces, and Films 36, 01 A119 (2017);

$10.1116 / 1.5003388$

Electron-enhanced atomic layer deposition of silicon thin films at room temperature Journal of Vacuum Science \& Technology A: Vacuum, Surfaces, and Films 36, 01 A118 (2017); $10.1116 / 1.5006696$

Plasma-enhanced atomic layer deposition of tungsten oxide thin films using $\left({ }^{\mathrm{t}} \mathrm{BuN}\right)_{2}\left(\mathrm{Me}_{2} \mathrm{~N}\right)_{2} \mathrm{~W}$ and $\mathrm{O}_{2}$ plasma Journal of Vacuum Science \& Technology A: Vacuum, Surfaces, and Films 36, 01 B103 (2017); $10.1116 / 1.4986202$

Spatial molecular layer deposition of polyamide thin films on flexible polymer substrates using a rotating cylinder reactor

Journal of Vacuum Science \& Technology A: Vacuum, Surfaces, and Films 36, 01 A117 (2017);

10.1116/1.5004041

\section{Instruments for Advanced Science}

Contact Hiden Analytical for further details: w www.HidenAnalytical.com E info@hiden.co.uk CLICK TO VIEW our product catalogue

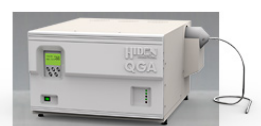

Gas Analysis

dynamic measurement of reaction gas streams

catalysis and thermal analysis

- molecular beam studies

'molecular beam studes

' dissolved spectes probes

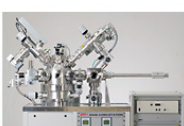

Surface Science

UHVTPD

SIMS

end point detection in ion beam etch elemental imaging-surface mapoing

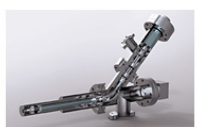

Plasma Diagnostics

plasma source characterization etch and deposition process reaction kinetic studies analysis of neutral and radical species

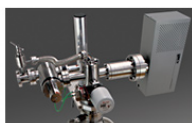

Vacuum Analysis , partial pressure measurement and contro of process gases reactive sputter process control vacuum diagnostics , vacuum coating process monitorin 


\title{
Tribological properties of thin films made by atomic layer deposition sliding against silicon
}

\author{
Lauri Kilpi, ${ }^{\text {a) }}$ Oili M. E. Ylivaara, and Antti Vaajoki \\ VTT Technical Research Centre of Finland, Ltd., P.O. Box 1000, FI-02044 VTT, Finland
}

Xuwen Liu and Ville Rontu

Department of Chemistry and Materials Science, Aalto University School of Chemical Engineering, P.O. Box 16100, FI-00076 Aalto, Finland

\begin{abstract}
Sakari Sintonen
Department of Electronics and Nanoengineering, Aalto University School of Electrical Engineering, P.O. Box 13500, FI-00076 Aalto, Finland
\end{abstract}

Eero Haimi

Department of Chemistry and Materials Science, Aalto University School of Chemical Engineering, P.O. Box 16100, FI-00076 Aalto, Finland

Jari Malm

Department of Physics, University of Jyväskylä, P.O. Box 35, FI-40014 Jyväskylä, Finland

Markus Bosund

Beneq, Ltd., Ensimmäinen savu, FI-01510 Vantaa, Finland

Marko Tuominen

ASM Microchemistry, Ltd., Pietari Kalmin katu 1 F 2, FI-00560 Helsinki, Finland

Timo Sajavaara

Department of Physics, University of Jyväskylä, P.O. Box 35, FI-40014 Jyväskylä, Finland

Harri Lipsanen

Department of Electronics and Nanoengineering, Aalto University School of Electrical Engineering, P.O. Box 13500, FI-00076 Aalto, Finland

\author{
Simo-Pekka Hannula \\ Department of Chemistry and Materials Science, Aalto University School of Chemical Engineering, \\ P.O. Box 16100, FI-00076 Aalto, Finland
}

Riikka L. Puurunen

Department of Chemical and Metallurgical Engineering, Aalto University School of Chemical Engineering, P.O. Box 16100, FI-00076 Aalto, Finland and VTT Technical Research Centre of Finland, Ltd., P.O. Box 1000, FI-02044 VTT, Finland

Helena Ronkainen

VTT Technical Research Centre of Finland, Ltd., P.O. Box 1000, FI-02044 VTT, Finland

(Received 7 September 2017; accepted 28 November 2017; published 29 December 2017)

Interfacial phenomena, such as adhesion, friction, and wear, can dominate the performance and reliability of microelectromechanical (MEMS) devices. Here, thin films made by atomic layer deposition (ALD) were tested for their tribological properties. Tribological tests were carried out with silicon counterpart sliding against ALD thin films in order to simulate the contacts occurring in the MEMS devices. The counterpart was sliding in a linear reciprocating motion against the ALD films with the total sliding distances of 5 and $20 \mathrm{~m} . \mathrm{Al}_{2} \mathrm{O}_{3}$ and $\mathrm{TiO}_{2}$ coatings with different deposition temperatures were investigated in addition to $\mathrm{Al}_{2} \mathrm{O}_{3}-\mathrm{TiO}_{2}$-nanolaminate, $\mathrm{TiN}, \mathrm{NbN}$, TiAlCN, a-C:H [diamondlike carbon (DLC)] coatings, and uncoated $\mathrm{Si}$. The formation of the tribolayer in the contact area was the dominating phenomenon for friction and wear performance. Hardness, elastic modulus, and crystallinity of the materials were also investigated. The nitride coatings had the most favorable friction and wear performance of the ALD coatings, yet lower friction coefficient was measured with DLC a-C:H coating. These results help us to take steps toward improved coating solutions in, e.g., MEMS applications. Published by the AVS. https://doi.org/10.1116/1.5003729

\section{INTRODUCTION}

Atomic layer deposition (ALD) is a chemical vapor deposition method which allows growth of uniform coatings on complicated 3D geometries. ${ }^{1-3}$ ALD technique is based on

a)Electronic mail: lauri.kilpi@vtt.fi sequential gas-solid reactions that are self-terminating; ALD operates by exposing a solid surface alternately to reactive gaseous chemicals, the exposures being separated by purge/ evacuation. ${ }^{1-3}$

ALD has been developed (under different names) since the 1960 s. $^{4}$ One of the main motivations for the recent development of ALD has been semiconductor processing, where the 
miniaturization requires precise thickness control over three dimensional substrates. ${ }^{3}$ The films deposited by ALD are also used in microelectromechanical system (MEMS) where the major benefit of ALD is the combination of low deposition temperatures (often under $300^{\circ} \mathrm{C}$ ) with conformal coatings, a combination rarely achieved by conventional coating processes. $^{5}$ The first reports of ALD for MEMS date from a decade ago and dealt with ALD as a tribological coating ${ }^{6}$ and an insulating layer. ${ }^{7}$ Since then, ALD films have been demonstrated, e.g., as dielectric layers in radio frequency (RF) MEMS, ${ }^{8}$ lubricating films,${ }^{9}$ insulator in MEMS compass, ${ }^{10,11}$ mirrors in Fabry-Perot interferometers for visible light, ${ }^{12,13}$ antistiction layers, ${ }^{14}$ and nanoelectromechanical system switches. ${ }^{15}$

Single crystal silicon is a highly desirable material for implementing MEMS due to its reliable and reproducible mechanical and electrical properties. ${ }^{16}$ Without any constraints the crystal growth direction (111) is favored, providing the highest atomic packing density and also the slowest growth rate of all the possible planes. The (111) oriented silicon slices used to be the standard for the industry, but structures like (100) and (110) have become more and more common lately, especially with the help of beam lead technology and dielectric isolated structures. The crystal orientation of silicon has an effect on certain anisotropic material properties, e.g., elastic modulus, hardness, and etch rate. ${ }^{17}$ Also, friction behavior has been reported to change with the different crystal structures of $\mathrm{Si}^{18,19}$

The performance and reliability of the MEMS devices can be dominated by interfacial phenomena, such as adhesion, friction, and wear., ${ }^{6,20,21}$ Understanding and controlling the friction and wear properties is crucial, especially with moving parts, which can be in contact intentionally or unintentionally during device operation. The friction and wear performance of materials can be studied with various test methods using various contacts, loads, and velocity conditions. Pin-on-disk test is one typical method using a pin sliding against a flat disk. The pin can have different geometries, such as spherical or flat-ended surface. Frictional force is recorded during the experiment and the wear of the pin and the disk are inspected after the experiments, e.g., by microscope or profilometry. Besides the wear of contacting materials, the formation of tribolayers on one or both of the surfaces typically occurs. Earlier studies related to friction and wear of ALD coatings include, e.g., $\mathrm{ZnO}, \mathrm{WS}_{2}$, and $\mathrm{Zn}_{\mathrm{x}} \mathrm{Ti}_{\mathrm{y}} \mathrm{O}_{\mathrm{z}}$ with mainly $\mathrm{Si}_{3} \mathrm{~N}_{4}$ used as counterpart. ${ }^{22-26}$ It is also claimed ${ }^{27,28}$ that the ALD $\mathrm{Al}_{2} \mathrm{O}_{3}$ coating deposited at $50^{\circ} \mathrm{C}$ does not form a tribolayer during sliding contact resulting in a low friction coefficient.

Diamond-like carbon (DLC) coatings provide low friction and good wear resistance for many practical applications and contact conditions, and the DLC coatings have been under extensive research for decades. ${ }^{29-31}$ Hydrogenated amorphous carbon (a-C:H) type DLC films can provide low friction performance in different atmospheres and with different contact parameters ${ }^{31}$ and they are widely in use. The friction coefficient of a-C:H coatings against steel materials in normal atmosphere is in the range of 0.1 to 0.2 (Ref. 32) and friction measurements against ceramic materials, such as
$\mathrm{Al}_{2} \mathrm{O}_{3}$ coatings, provide low values, even down to $0.02,{ }^{32}$ depending on the test parameters.

The goal of this work is to investigate the tribological properties of conventional and some potential ALD coatings usable in MEMS applications. Since silicon is a widely used substrate material in MEMS and tribological properties of ALD films on silicon are of the interest of this study, we developed the method for simulating the tribological contact between silicon and ALD films under reciprocating sliding. A hemispherical pin fabricated from single crystal silicon was used as a counterpart for ALD films. A DLC (a-C:H) film was used as a reference as the coating provides an excellent reference for the tribological performance also for the ALD films studied in this research. The friction performance of a-C:H against silicon is not well known, and therefore, this study is also broadening the understanding of a$\mathrm{C}: \mathrm{H}$ coating behavior in different contact situations.

\section{EXPERIMENT}

\section{A. Sample preparation \\ 1. Disk samples}

As substrates for ALD coatings, single and double side polished $150 \mathrm{~mm}$-type $\langle 100\rangle$ silicon wafers with thickness of 675 and $380 \mu \mathrm{m}$, respectively, were used. Wafers were cleaned before the ALD using standard Radio Corporation of America cleaning baths ( $\mathrm{SC} 1, \mathrm{HF}$, and $\mathrm{SC} 2)^{33}$ as described in earlier publication by Ylivaara et al. ${ }^{34}$ Studied ALD coatings, described in Table I, were aluminum oxide $\left(\mathrm{Al}_{2} \mathrm{O}_{3}\right)$, titanium dioxide $\left(\mathrm{TiO}_{2}\right), \mathrm{Al}_{2} \mathrm{O}_{3}-\mathrm{TiO}_{2}$ nanolaminates (later ATO nanolaminate), plasma-enhanced ALD (PEALD) titanium nitride $(\mathrm{TiN})$, niobium nitride $(\mathrm{NbN})$, and titanium aluminum carbonitride (TiAlCN). The different coatings studied are listed in Table I.

Aluminum oxide $\left(\mathrm{Al}_{2} \mathrm{O}_{3}\right)$, titanium dioxide $\left(\mathrm{TiO}_{2}\right)$, and ATO nanolaminate were deposited in a top-flow Picosun R150 ALD reactor. Precursors were trimethylaluminum $\left(\mathrm{Me}_{3} \mathrm{Al}\right)$, titanium tetrachloride $\left(\mathrm{TiCl}_{4}\right)$, and water $\left(\mathrm{H}_{2} \mathrm{O}\right)$. Electronic grade $\mathrm{Me}_{3} \mathrm{Al}$ and $\mathrm{TiCl}_{4}$ precursors were from SAFC Hitech. Nitrogen (purity $>99.999 \%$ ) was used both as a purge gas and for flushing the reactant lines with a constant $200 \mathrm{sccm}$ flow. The intermediate space pressure in the reactor was about $700 \mathrm{~Pa} . \mathrm{Me}_{3} \mathrm{Al}$ and $\mathrm{TiCl}_{4}$ precursors were cooled with a Peltier element to about 17 and $14{ }^{\circ} \mathrm{C}$, respectively. Water was used at a room temperature without cooling. $\mathrm{ALD} \mathrm{Al}_{2} \mathrm{O}_{3}$ and $\mathrm{TiO}_{2}$ samples were deposited using $0.1-4.0-0.1-4.0 \mathrm{~s}$ pulse sequence for metal precursor pulse-purge- $\mathrm{H}_{2} \mathrm{O}$ pulse-purge at a temperature range from 110 to $200^{\circ} \mathrm{C}$. For $\mathrm{Al}_{2} \mathrm{O}_{3}$ and $\mathrm{TiO}_{2}$ samples deposited at $300^{\circ} \mathrm{C}$, shorter pulse sequence was used, namely, $0.1-1.0-0.1-1.0 \mathrm{~s}$ for metal precursor pulse-purge- $\mathrm{H}_{2} \mathrm{O}$ pulse-purge. Targeted layer thicknesses were 100 and $300 \mathrm{~nm}$ for $\mathrm{Al}_{2} \mathrm{O}_{3}$, and $100 \mathrm{~nm}$ for $\mathrm{TiO}_{2}$ coatings. In ATO nanolaminate targeted total thickness was $100 \mathrm{~nm}$ with about $5 \mathrm{~nm}$ bilayer thickness (composed of $2 \mathrm{~nm} \mathrm{Al}_{2} \mathrm{O}_{3}$ and $3 \mathrm{~nm} \mathrm{TiO}_{2}$ sublayers) as described in Ref. 35. Targeted $\mathrm{TiO}_{2}$ content in the nanolaminate was $60 \%$. ATO nanolaminate was deposited at $200^{\circ} \mathrm{C}$ from sequential $\mathrm{Al}_{2} \mathrm{O}_{3}$ and $\mathrm{TiO}_{2}$ layers, using pulse sequence with $4.0 \mathrm{~s}$ purges. The structure of the nanolaminate started 
TABLE I. Summary of the samples evaluated for tribological properties in this work.

\begin{tabular}{lcc}
\hline \hline Coating & $\begin{array}{c}\text { Target coating } \\
\text { thickness }(\mathrm{nm})\end{array}$ & $\begin{array}{c}\text { Deposition } \\
\text { temperature }\left({ }^{\circ} \mathrm{C}\right)\end{array}$ \\
\hline Si reference sample & - & - \\
$\mathrm{Al}_{2} \mathrm{O}_{3}$ low temperature & 100 & 50 \\
$\mathrm{Al}_{2} \mathrm{O}_{3}$ temperature series & 300 & $110,150,200,250,300$ \\
$\mathrm{TiO}_{2}$ temperature series & 100 & $110,150,200,250,300$ \\
$\mathrm{ATO}_{\mathrm{T}}$ temperature series & 100 & $110,150,200,250,300$ \\
$\mathrm{TiN}$ & 100 & 300 \\
$\mathrm{NbN}$ & 100 & 400 \\
$\mathrm{TiAlCN}$ & 100 & 400 \\
$\mathrm{DLC}$ & 85 & 200 \\
\hline \hline
\end{tabular}

with $\mathrm{Al}_{2} \mathrm{O}_{3}$ layer followed by the $\mathrm{TiO}_{2}$. The total nanolaminate structure was capped with an about $2 \mathrm{~nm}$ in thickness $\mathrm{Al}_{2} \mathrm{O}_{3}$ layer.

Low-temperature $\mathrm{ALD} \mathrm{Al}_{2} \mathrm{O}_{3}$ film was grown at $50^{\circ} \mathrm{C}$ in a Beneq TFS 200 ALD reactor at 150 Pa pressure. Precursors $\left(\mathrm{Me}_{3} \mathrm{Al}\right.$ and $\left.\mathrm{H}_{2} \mathrm{O}\right)$ were evaporated by means of their own vapor pressure from external precursor bottles kept at $20^{\circ} \mathrm{C}$. Electronic grade $\mathrm{Me}_{3} \mathrm{Al}$ precursor was from SAFC Hitech. Nitrogen was used as the purge gas and it was generated from compressed particle-free dry air by an Inmatec PN1150 molecular sieve nitrogen separator (purity $>99.999 \%$ ). The precursor pulses were kept at $0.15 \mathrm{~s}$ and the purge periods following the $\mathrm{Me}_{3} \mathrm{Al} / \mathrm{H}_{2} \mathrm{O}$ precursor pulse was 7 and $20 \mathrm{~s}$. The number of deposition cycles was aimed at a $100 \mathrm{~nm}$ film thickness.

ALD TiAlCN films were grown in ASM's EmerALD ${ }^{\circledR}$ showerhead single-wafer ALD reactor using $\mathrm{TiCl}_{4}$ (SigmaAldrich 99.9\%), $\mathrm{Me}_{3} \mathrm{Al}$ (SAFC Hitech Electronic grade) and ammonia $\left(\mathrm{NH}_{3}\right)$ (AGA 5.0 with purifier) as precursors and nitrogen (AGA High Tech with purifier) as carrier and purge gas. The precursors were kept at room temperature of about $21^{\circ} \mathrm{C}$.

PEALD TiN layers were grown in a Beneq TFS 200. Precursor purity was $99.999 \%$ or better. Nitrogen was used as the carrier gas. Titanium tetrachloride $\left(\mathrm{TiCl}_{4}\right)$ and ammonia plasma were used as the precursors. The reactor temperature was $300^{\circ} \mathrm{C}$.

Niobium nitride $(\mathrm{NbN})$ thin films were grown as described in Ref. 36 in a top-flow Picosun R-200 ALD reactor equipped with a load-lock. Precursors used were research grade niobium pentachloride $\left(\mathrm{NbCl}_{5}\right)$ (SAFC Hitech) and $\mathrm{NH}_{3}$ (purity $>99.999 \%$ ) with nitrogen as the carrier gas. As substrate, $300 \mu \mathrm{m}$ thick $100 \mathrm{~mm}$ p-type $\langle 100\rangle \mathrm{Si}$ wafer was used, cleaned with SC1 and HF. Deposition was carried out at $400{ }^{\circ} \mathrm{C}$ using $1.5-5.0$ and $1.0-6.0 \mathrm{~s}$ pulse-purge sequence for $\mathrm{NbN}$ and $\mathrm{NH}_{3}$, respectively. The number of deposition cycles used were 3600 , aiming for $100 \mathrm{~nm}$ film thickness.

The DLC coatings were deposited for this study with the capacitively coupled RF plasma device with a plasma enhanced chemical vapor deposition method. The substrates were placed directly on the powered cathode, and methane $\left(\mathrm{CH}_{4}\right)$ was used as the source gas to deposit amorphous hydrogenated (a-C:H) coatings on silicon wafer. Prior to deposition, the substrates were sputter cleaned in argon plasma. The pressure was $6 \mathrm{~Pa}$ and the bias voltage $-500 \mathrm{~V}$ during the deposition. The deposition temperature was about $200{ }^{\circ} \mathrm{C}$, and the growth rate of the coating was $0.5 \mu \mathrm{m} / \mathrm{h}$. The final coating thickness was $85 \mathrm{~nm}$. The DLC films were used as the reference coating for the ALD films.

\section{Pin samples}

The pin samples were attached on $8 \mathrm{~mm}$ thick aluminum disks (Al 6082, diameter $40 \mathrm{~mm}$ ) using glue (Henkel's Loctite 401) to ensure firm fastening in the test device. Different glues were compared and the selected one provided the most stable performance with no effects on the silicon system under increasing load. The counter surface was a pin with a top part fabricated of bulk single crystal silicon. The surface of the silicon part, presented in Fig. 1 with disk sample, was hemispherical with a $50 \mathrm{~mm}$ radius of curvature; it was polished to mirror finish and cleaned before testing with petroleum ether, ethanol and acetone. The indentation hardness and modulus, measured using the microcombi tester (MCT), were $\mathrm{H}_{I T}=9.8 \pm 0.7 \mathrm{GPa}$ and $E_{I T}=202 \pm 15 \mathrm{GPa}$, respectively. The arithmetic average surface roughness of the Si pin contact surface, measured using Mitutoyo Formtracer SV-C-3100 2D-profilometry, was $\mathrm{Ra}=0.004 \pm 0.001 \mu \mathrm{m}$.

\section{B. Coating characterization}

\section{1. $X R R$}

The thickness values of the ALD films were determined by $\mathrm{X}$-ray reflectivity (XRR). ${ }^{37,38}$ In XRR, X-rays are specularly reflected from interfaces of materials with different electron densities, and the influence of layer thicknesses on the reflected X-ray intensity may be recursively calculated as a function of scattering angle. ${ }^{39}$ The XRR measurements were performed under parallel beam conditions using a Philips X'Pert Pro diffractometer. The acceleration voltage, anode current, and x-ray wavelength were $40 \mathrm{kV}, 40 \mathrm{~mA}$, and $\mathrm{Cu}-\mathrm{K}_{\alpha}$, respectively. The film thickness values were obtained through simulation of XRR measurement curves using the software X'PERT REFLECTIVITY.

\section{GIXRD}

Grazing incidence $x$-ray diffraction (GIXRD) was used to study the crystallinity of the samples. In GIXRD, the incident angle is set to a small value slightly larger than the critical
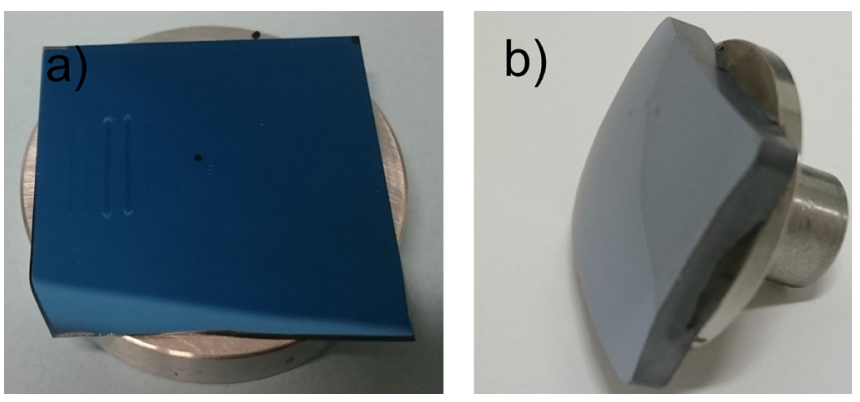

FIG. 1. (Color online) Samples used in the experiments: (a) ALD coated Si wafer glued on the $\mathrm{Al}$ disk with the wear tracks of reciprocating sliding tests shown on the surface, and (b) the pin with a hemispherical silicon top part. 
angle of total external reflection. The incident angle is kept constant during the measurement, while the scattering angle is scanned. Thanks to the small incident angle, GIXRD probes a much larger volume than conventional powder diffraction, enabling diffraction to be recorded from films with thicknesses of only a few tens of nanometers. The GIXRD experiments were conducted using the same parallel beam setup and conditions as the XRR measurements. The incident angle was fixed at $\omega=0.5^{\circ}$.

\section{Nanoindentation}

Nanoindentation measurements were carried out with a Hysitron TriboIndenter ${ }^{\circledR}$ TI-900 nanomechanical testing system. Measurements were done in a semiclean room with constant laminar airflow to minimize the possible thermal drift during the measurements. Indentations were performed under load-control mode with the loading, holding at peakload and unloading segment times of 10,5 , and $5 \mathrm{~s}$, respectively.

A cube-corner indenter with a $90^{\circ}$ total induced angle and a tip radius under $40 \mathrm{~nm}$ was used in the study. The purpose of using a sharp tip was to trigger plastic deformation at shallow indents, less than $10 \%$ of the film thickness, in order to measure the film hardness with minimal substrate effects.

The mechanical properties of the indented material were extracted from a series of load and depth data using the Oliver and Pharr method, ${ }^{40}$ where the elastic modulus of the film $E_{f}$ and the diamond tip, $E_{i}$ are related to the contact modulus, $E^{*}$, through the following equation:

$$
\frac{1}{E^{*}}=\frac{1-v_{i}^{2}}{E_{i}}+\frac{1-v_{f}^{2}}{E_{f}},
$$

where $v_{i}$ and $v_{f}$ are the Poisson's ratio for the diamond tip and grown film (or the Si reference), respectively. For the diamond tip, $1140 \mathrm{GPa}$ and 0.07 were used for $E_{i}$ and $v_{i}$, respectively. Poisson's ratio of $v_{f}=0.24$ (Ref. 41) was used for the $\mathrm{Al}_{2} \mathrm{O}_{3}, 0.28$ for $\mathrm{TiO}_{2},{ }^{42} 0.30$ for $\mathrm{NbN},{ }^{43} 0.23$ for PEALD TiN (Ref. 44) films, and 0.25 for silicon. For ATO nanolaminate and TiAlCN coatings, contact modulus value are calculated instead. Reference values 45 are given in a wide range for Poisson's ratios of Si, 0.048-0.403, due to the anisotropic nature of Si. The average value used in this study should be reasonable considering the orientation of $\mathrm{Si}$ in our case. The hardness of the film is defined as the maximum indentation load divided by the contact area corresponding to the $\operatorname{load}^{46}$

$$
H=\frac{P_{\max }}{A} .
$$

The instrument stability and indentation repeatability were monitored by performing a series of 16 indents into a piece of silicon wafer over a period of time with the peak load varying from 5 to $500 \mu \mathrm{N}$. The silicon reference sample was taken from the same wafer batch that was used as the substrate for the $\mathrm{Al}_{2} \mathrm{O}_{3}$ films. The indenter conditions (tip rounding) were also checked throughout the measurement by indenting on the standard fused quartz to see the need of the tip area function for recalibration.

\section{Tribological testing}

Tribological tests were designed to simulate the contact conditions occurring in MEMS. The MCT (Anton Paar Tritec) and pin-on-disk tribometer (tribometer 1) (Anton Paar Tritec) were used for friction and wear evaluation in reciprocating motion. The silicon pin was rotated to provide new contact surface for each test. Therefore, the crystal orientation varied between the tests, which might have caused some variation in the friction performance of the coatings.

\section{Stepwise reciprocative sliding}

The Si pin was sliding back and forth against the coated wafers with a constant load to perform the reciprocating sliding motion. The constant load of $300 \mathrm{mN}$ was used during the tests, the sliding speed was $0.01 \mathrm{~m} \mathrm{~s}^{-1}$, and the length of the sliding pass in one direction was $10 \mathrm{~mm}$. In the tests carried out with the MCT, the movement was stopped for about $1 \mathrm{~s}$ after each sliding pass before sliding to opposite direction. The testing was carried out stepwise manner using five steps. During each step, the Si pin was sliding the selected number of passes on the coated disk after which optical microscopy (OM) was used to investigate the status of the coating. Optical microscopy was used after the steps of 50, 100, 200, 300, and 500 sliding passes which formed the basic routine. The sliding distance of 500 passes generated the total sliding distance of $5 \mathrm{~m}$. The coatings that showed low wear were tested with 500 extra passes after the basic test routine. During the tests friction force was measured to determine the friction coefficient. For the tests carried out in stepwise manner using the MCT device, the average friction values were determined for the 1st, 100th, 200th, 300th, 400th, and 500th sliding pass as the mean value of one sliding cycle representing the friction performance.

\section{Continuous reciprocative sliding}

The materials with high friction performance were selected for further studies. The continuous reciprocating sliding tests were carried out for selected samples with the tribometer 1 using the sliding distances of $5 \mathrm{~m}$ (500 cycles) and $20 \mathrm{~m}$ (2000 cycles) in order to compare the long term performance of coatings. The constant load was $300 \mathrm{mN}$, the sliding speed was $0.01 \mathrm{~ms}^{-1}$, and the length of the sliding pass in one direction was $10 \mathrm{~mm}$ as in previous tests. In this test procedure, the sliding was continuous without pauses between the $10 \mathrm{~mm}$ unidirectional sliding cycles before the change in direction. In these continuous reciprocating sliding tests, recorded friction data had either a positive or negative sign, depending on the sliding direction. Here for clarity, the absolute values were combined to create the continuous friction curves shown in this paper. Moving average (consisting of 1000 points) was also created and plotted in the friction graphs. Two to three repeated tests were carried out for all the coatings, and the experiments were carried out in the 
TABLE II. Thickness, deposition temperature, hardness, elastic modulus, and crystallinity of the ALD coatings studied.

\begin{tabular}{lccccc}
\hline \hline & & & & Elastic \\
ALD films & $\begin{array}{c}\text { Temperature } \\
\left({ }^{\circ} \mathrm{C}\right)\end{array}$ & $\begin{array}{c}\text { Thickness } \\
(\mathrm{nm})\end{array}$ & $\begin{array}{c}\text { Hardness } \\
(\mathrm{GPa})\end{array}$ & $\begin{array}{c}\text { modulus } \\
(\mathrm{GPa})\end{array}$ & Crystallinity \\
\hline $\mathrm{Si} \mathrm{reference}$ & - & - & - & - & - \\
$\mathrm{Al}_{2} \mathrm{O}_{3}$ & 50 & 98 & $6.1 \pm 0.3$ & $135 \pm 27$ & Amorphous \\
$\mathrm{Al}_{2} \mathrm{O}_{3}$ & 110 & $288^{\mathrm{a}}$ & $7.9 \pm 0.2^{\mathrm{a}}$ & $139 \pm 9^{\mathrm{a}}$ & Amorphous \\
$\mathrm{Al}_{2} \mathrm{O}_{3}$ & 150 & $285^{\mathrm{a}}$ & $10.0 \pm 0.2^{\mathrm{a}}$ & $171 \pm 12^{\mathrm{a}}$ & Amorphous \\
$\mathrm{Al}_{2} \mathrm{O}_{3}$ & 200 & $287^{\mathrm{a}}$ & $9.8 \pm 0.3^{\mathrm{a}}$ & $167 \pm 11^{\mathrm{a}}$ & Amorphous \\
$\mathrm{Al}_{2} \mathrm{O}_{3}$ & 250 & $292^{\mathrm{a}}$ & $11.1 \pm 0.7^{\mathrm{a}}$ & $178 \pm 15^{\mathrm{a}}$ & Amorphous \\
$\mathrm{Al}_{2} \mathrm{O}_{3}$ & 300 & $284^{\mathrm{a}}$ & $10.5 \pm 0.6^{\mathrm{a}}$ & $170 \pm 10^{\mathrm{a}}$ & Amorphous \\
$\mathrm{TiO}_{2}$ & 110 & 97 & $6.9 \pm 0.1$ & $152 \pm 5$ & Amorphous \\
$\mathrm{TiO}_{2}$ & 150 & 103 & $7.3 \pm 0.1$ & $149 \pm 4$ & Amorphous \\
$\mathrm{TiO}_{2}$ & 200 & 91 & $8.5 \pm 1.0$ & $154 \pm 9$ & Anatase \\
$\mathrm{TiO}_{2}$ & 250 & 105 & $10.5 \pm 0.8$ & $159 \pm 7$ & Anatase \\
$\mathrm{TiO}_{2}$ & 300 & 104 & $11.3 \pm 1.9$ & $196 \pm 30$ & Anatase \\
$\mathrm{ATO}_{\mathrm{ATO}}$ & 110 & $101^{\mathrm{b}}$ & $6.8 \pm 0.4^{\mathrm{b}}$ & $140 \pm 12^{\mathrm{b}}$ & Amorphous \\
$\mathrm{ATO}_{\mathrm{ATO}}$ & 150 & $103^{\mathrm{b}}$ & $7.4 \pm 0.2^{\mathrm{b}}$ & $147 \pm 5^{\mathrm{b}}$ & Amorphous \\
$\mathrm{ATO}$ & 200 & $99^{\mathrm{b}}$ & $7.3 \pm 0.4^{\mathrm{b}}$ & $147 \pm 8^{\mathrm{b}}$ & Amorphous \\
$\mathrm{PEALD} \mathrm{TiN}$ & 300 & $84^{\mathrm{b}}$ & $8.2 \pm 0.2^{\mathrm{b}}$ & $155 \pm 9^{\mathrm{b}}$ & Amorphous \\
$\mathrm{TiAlCN}_{\mathrm{NaN}}$ & 300 & $84^{\mathrm{b}}$ & $8.6 \pm 0.2^{\mathrm{b}}$ & $156 \pm 5^{\mathrm{b}}$ & Amorphous \\
$\mathrm{NbN}$ & 400 & 65 & $18.9 \pm 0.9$ & $186 \pm 33$ & Rock salt \\
\hline \hline
\end{tabular}

${ }^{\mathrm{a}}$ Values from Ref. 34.

${ }^{\mathrm{b}}$ Values from Ref. 35 .

controlled environment with temperature $22 \pm 1{ }^{\circ} \mathrm{C}$ and relative humidity $50 \pm 5 \% \mathrm{RH}$.

\section{Microscopy and profilometry}

After the experiments, OM was used to investigate the wear tracks of both the pin and the disk. The 3D profilometry (Sensofar $\mathrm{Pl} \mu$ 2300) was used to characterize the wear surfaces and 2D profilometry (Mitutoyo Formtracer SV$\mathrm{C} 3100 \mathrm{H} 4)$ to determine the volumes of the coating wear. To determine the wear volumes of the coatings, the $2 \mathrm{D}$ profiles were taken across the wear track in three locations. The wear of the silicon pin was determined based on the OM of the wear surface. The wear rates were calculated by dividing the wear volumes by load and sliding distance. Selected samples were also analyzed by using scanning electron microscopy (SEM) with energy-dispersive $\mathrm{x}$-ray spectroscopy (EDS) (FEI XL 30 ESEM). EDS analysis was carried out with $15 \mathrm{kV}$ accelerating voltage.

\section{RESULTS}

\section{A. Coating characteristics}

The coating hardness and Young's modulus values obtained by nanoindentation are presented in Table II, presenting also the crystallinity and the coating thickness values characterized by $\mathrm{x}$-ray reflectivity. ALD NbN and PEALD TiN have clearly higher hardness values than the rest of the materials. Most of the ALD films were amorphous, but PEALD TiN, NbN, and the $\mathrm{TiO}_{2}$ films deposited at temperatures $200{ }^{\circ} \mathrm{C}$ and higher, showed crystal structure in GIXRD measurements (Fig. 2). Since GIXRD measurements measures randomly oriented grains, the high peak intensities of $\mathrm{TiO}_{2}$ and $\mathrm{NbN}$ films suggest no preferred orientation in the films. The lower peak intensity of TiN films on the other hand is probably related to a lower fraction of crystalline material or lower quality of the crystalline structure. The lower density of $6.65 \mathrm{~g} / \mathrm{cm}^{3}$ of the ALD-NbN, as measured by XRR, compared with the tabulated value of $8.47 \mathrm{~g} / \mathrm{cm}^{3}$ of crystalline $\mathrm{NbN}$ supports this conclusion. The crystalline $\mathrm{TiO}_{2}$ films showed anatase phase with increased the surface roughness of the $\mathrm{TiO}_{2}$ film, particularly for the film deposited at $300{ }^{\circ} \mathrm{C}$.

\section{B. Friction performance of ALD coatings}

The friction coefficient values measured in the reciprocating sliding tests with $\mathrm{Si}$ pins acting as the counter material against the ALD coatings are listed in Table III representing the values after $0.01,1,5$, and $20 \mathrm{~m}$ sliding.

\section{Stepwise reciprocative sliding tests}

a. $\mathrm{Al}_{2} \mathrm{O}_{3}$. The $\mathrm{ALD} \mathrm{Al}_{2} \mathrm{O}_{3}$ coatings deposited in different temperatures had low friction coefficient around 0.2 to 0.3 in the beginning of the test but after some sliding the friction increased to values in the range 0.4 to 0.6 , as shown in Table III and Fig. 3(a). The coatings grown at temperatures 110, 150 , and $250^{\circ} \mathrm{C}$ provided low friction performance for longer sliding distance than the other $\mathrm{Al}_{2} \mathrm{O}_{3}$ films. During the tests the friction increased also for these coatings reaching values around 0.5 in the end of the test. The $\mathrm{Al}_{2} \mathrm{O}_{3}$ coating that was deposited in the different reactor at $50{ }^{\circ} \mathrm{C}$ temperature had friction values similar to films deposited at 200 and $300^{\circ} \mathrm{C}$.

A typical feature for the $\mathrm{Al}_{2} \mathrm{O}_{3}$ films was the formation of a tribolayer on the sliding surface of the coating during the sliding tests as shown in Figs. 4(a) and 4(b). The Si pin experienced a noticeable amount of wear, as shown in Fig. 4(c). The increase in friction was most likely related to the formation of tribolayer on the sliding surface of the $\mathrm{Al}_{2} \mathrm{O}_{3}$ film since the tribolayer consisted of the worn and oxidized

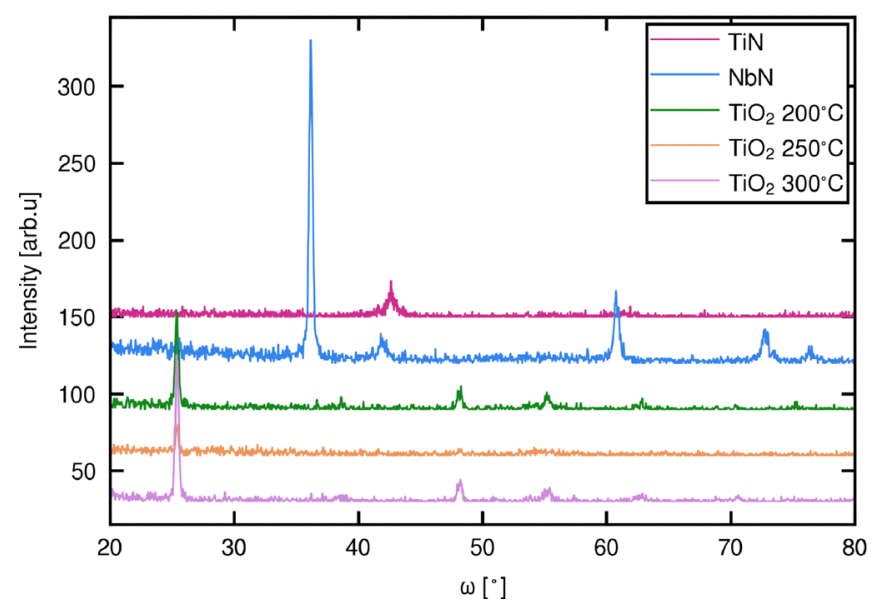

FIG. 2. (Color online) GIXRD graphs of all the crystalline samples: PEALD TiN $\left(100 \mathrm{~nm} / 300^{\circ} \mathrm{C}\right), \operatorname{ALD~NbN}\left(100 \mathrm{~nm} / 400^{\circ} \mathrm{C}\right), \operatorname{ALD~} \mathrm{TiO}_{2}(100 \mathrm{~nm} /$ $\left.200^{\circ} \mathrm{C}\right), \operatorname{ALD~TiO}_{2}\left(100 \mathrm{~nm} / 250^{\circ} \mathrm{C}\right)$ and $\operatorname{ALD~TiO}_{2}\left(100 \mathrm{~nm} / 300^{\circ} \mathrm{C}\right)$. 
TABLE III. Friction coefficient values of ALD coatings against silicon pin measured in reciprocative sliding tests with the two test procedures (stepwise sliding and continuous sliding). The average values from at least two repeated tests represent the friction measured after sliding distances of $0.01,1,5$, and $20 \mathrm{~m}$. The scatter of the results is shown as standard deviation.

\begin{tabular}{|c|c|c|c|c|c|c|c|c|c|}
\hline \multirow[b]{2}{*}{ Coating } & \multirow{2}{*}{$\begin{array}{l}\text { Temperature } \\
\left({ }^{\circ} \mathrm{C}\right)\end{array}$} & \multirow{2}{*}{$\begin{array}{l}\text { Thickness } \\
(\mathrm{nm})\end{array}$} & \multicolumn{3}{|c|}{$\begin{array}{l}\text { Reciprocative } \\
\text { stepwise sliding }\end{array}$} & \multicolumn{4}{|c|}{ Continuous reciprocative sliding } \\
\hline & & & $\mu(0.01 \mathrm{~m})$ & $\mu(1 \mathrm{~m})$ & $\mu(5 \mathrm{~m})$ & $\mu(0.01 \mathrm{~m})$ & $\mu(1 \mathrm{~m})$ & $\mu(5 \mathrm{~m})$ & $\mu(20 \mathrm{~m})$ \\
\hline Si reference & - & - & $0.22 \pm 0.10$ & $0.71 \pm 0.07$ & $0.70 \pm 0.06$ & $0.24 \pm 0.09$ & $0.51 \pm 0.10$ & $0.55 \pm 0.09$ & - \\
\hline $\mathrm{Al}_{2} \mathrm{O}_{3}$ & 50 & 98 & $0.19 \pm 0.07$ & $0.45 \pm 0.22$ & $0.63 \pm 0.10$ & $0.21 \pm 0.05$ & $0.39 \pm 0.13$ & $0.48 \pm 0.11$ & - \\
\hline $\mathrm{Al}_{2} \mathrm{O}_{3}$ & 110 & $288^{\mathrm{a}}$ & $0.28 \pm 0.08$ & $0.21 \pm 0.06$ & $0.52 \pm 0.11$ & - & - & - & - \\
\hline $\mathrm{Al}_{2} \mathrm{O}_{3}$ & 150 & $285^{\mathrm{a}}$ & $0.21 \pm 0.06$ & $0.21 \pm 0.08$ & $0.43 \pm 0.09$ & - & - & - & - \\
\hline $\mathrm{Al}_{2} \mathrm{O}_{3}$ & 200 & $287^{\mathrm{a}}$ & $0.26 \pm 0.05$ & $0.61 \pm 0.08$ & $0.48 \pm 0.09$ & - & - & - & - \\
\hline $\mathrm{Al}_{2} \mathrm{O}_{3}$ & 250 & $292^{\mathrm{a}}$ & $0.23 \pm 0.05$ & $0.20 \pm 0.05$ & $0.50 \pm 0.08$ & - & - & - & - \\
\hline $\mathrm{Al}_{2} \mathrm{O}_{3}$ & 300 & $284^{\mathrm{a}}$ & $0.23 \pm 0.07$ & $0.45 \pm 0.07$ & $0.53 \pm 0.08$ & $0.25 \pm 0.05$ & $0.25 \pm 0.05$ & $0.49 \pm 0.08$ & - \\
\hline $\mathrm{TiO}_{2}$ & 110 & 97 & $0.26 \pm 0.08$ & $0.24 \pm 0.08$ & $0.33 \pm 0.07$ & $0.26 \pm 0.12$ & $0.24 \pm 0.05$ & $0.43 \pm 0.16$ & - \\
\hline $\mathrm{TiO}_{2}$ & 150 & 103 & $0.43 \pm 0.10$ & $0.50 \pm 0.13$ & $0.69 \pm 0.06$ & - & - & - & - \\
\hline $\mathrm{TiO}_{2}$ & 200 & 91 & $0.56 \pm 0.10$ & $0.65 \pm 0.07$ & $0.65 \pm 0.07$ & - & - & - & - \\
\hline $\mathrm{TiO}_{2}$ & 250 & 105 & $0.68 \pm 0.11$ & $0.56 \pm 0.10$ & $0.51 \pm 0.08$ & - & - & - & - \\
\hline $\mathrm{TiO}_{2}$ & 300 & 104 & $0.67 \pm 0.13$ & $0.66 \pm 0.10$ & $0.60 \pm 0.12$ & $0.71 \pm 0.26$ & $0.63 \pm 0.10$ & $0.55 \pm 0.08$ & - \\
\hline ATO & 110 & $101^{\mathrm{b}}$ & $0.24 \pm 0.05$ & $0.22 \pm 0.07$ & $0.25 \pm 0.06$ & - & - & - & - \\
\hline ATO & 150 & $103^{\mathrm{b}}$ & $0.22 \pm 0.06$ & $0.21 \pm 0.06$ & $0.44 \pm 0.10$ & $0.25 \pm 0.05$ & $0.19 \pm 0.04$ & $0.26 \pm 0.10$ & $0.53 \pm 0.07$ \\
\hline ATO & 200 & $99^{\mathrm{b}}$ & $0.20 \pm 0.05$ & $0.21 \pm 0.06$ & $0.17 \pm 0.08$ & & & & \\
\hline ATO & 250 & $84^{\mathrm{b}}$ & $0.20 \pm 0.04$ & $0.28 \pm 0.06$ & $0.49 \pm 0.16$ & $0.24 \pm 0.04$ & $0.19 \pm 0.03$ & $0.43 \pm 0.10$ & - \\
\hline ATO & 300 & $84^{\mathrm{b}}$ & $0.33 \pm 0.06$ & $0.19 \pm 0.09$ & $0.26 \pm 0.07$ & - & - & - & - \\
\hline PEALD TiN & 300 & 116 & $0.51 \pm 0.17$ & $0.29 \pm 0.07$ & $0.34 \pm 0.07$ & $0.78 \pm 0.30$ & $0.24 \pm 0.07$ & $0.27 \pm 0.07$ & $0.30 \pm 0.05$ \\
\hline TiAlCN & 400 & 65 & $0.28 \pm 0.07$ & $0.35 \pm 0.07$ & $0.32 \pm 0.08$ & $0.28 \pm 0.05$ & $0.28 \pm 0.06$ & $0.36 \pm 0.06$ & $0.44 \pm 0.08$ \\
\hline $\mathrm{NbN}$ & 400 & 106 & $0.29 \pm 0.09$ & $0.33 \pm 0.08$ & $0.36 \pm 0.08$ & $0.31 \pm 0.08$ & $0.20 \pm 0.04$ & $0.30 \pm 0.05$ & $0.33 \pm 0.03$ \\
\hline DLC reference & 200 & 85 & - & - & - & $0.22 \pm 0.13$ & $0.13 \pm 0.04$ & $0.12 \pm 0.05$ & - \\
\hline
\end{tabular}

${ }^{\mathrm{a}}$ Values from Ref. 34.

${ }^{\mathrm{b}}$ Values from Ref. 35 .

silicon and the sliding thus occurred between similar materials. Sliding between similar materials is known to increase the friction between the surfaces. ${ }^{47}$

b. $\mathrm{TiO}_{2}$. The friction performance of $\mathrm{ALD} \mathrm{TiO}_{2}$ on $\mathrm{Si}$ wafers grown at different temperatures is presented in Fig. 3(b). The friction of $\mathrm{TiO}_{2}$ was high (0.4-0.7) already in the beginning of the tests for $\mathrm{TiO}_{2}$ grown at 150 to $300^{\circ} \mathrm{C}$ compared to amorphous $\mathrm{TiO}_{2}$ sample deposited at $110^{\circ} \mathrm{C}$. The friction values was stabilized between 0.50 and 0.70 . The $\mathrm{TiO}_{2}$ coating grown at $110^{\circ} \mathrm{C}$ had an exceptionally low friction value of $0.2-0.4$ throughout the test.

The $\mathrm{TiO}_{2}$ coatings deposited at higher temperatures had high friction values (0.5-0.7), and formation of tribolayer on the coating wear track was observed, as can be seen in Fig. 5(a). The tribolayer formation was similar as observed for
$\mathrm{Al}_{2} \mathrm{O}_{3}$ films. On the other hand, as can be observed in Fig. 5 (b), no tribolayer was generated on the $\mathrm{TiO}_{2}$ grown at $110^{\circ} \mathrm{C}$ which had low friction in the tests. The Si pin suffered a noticeable amount of wear in all cases except when sliding against the coating deposited at $110^{\circ} \mathrm{C}$.

c. $\mathrm{Al}_{2} \mathrm{O}_{3}-\mathrm{TiO}_{2}$ nanolaminates. The results of the ALD ATO nanolaminate coatings deposited at temperatures 110 , 200 and $300{ }^{\circ} \mathrm{C}$ showed generally low friction values, in the range 0.20 to 0.30 , from start to finish. For the coatings deposited at 150 and $250{ }^{\circ} \mathrm{C}$, the friction values increased close to 0.50 during the 500 sliding passes ( $5 \mathrm{~m}$ sliding) test as presented in Fig. 3(c). The coatings with low friction had a smooth wear track without tribolayer formation as observed in Fig. 6(a). On the other hand, pin wear surface showed some layer formation visible in Fig. 6(b). For the
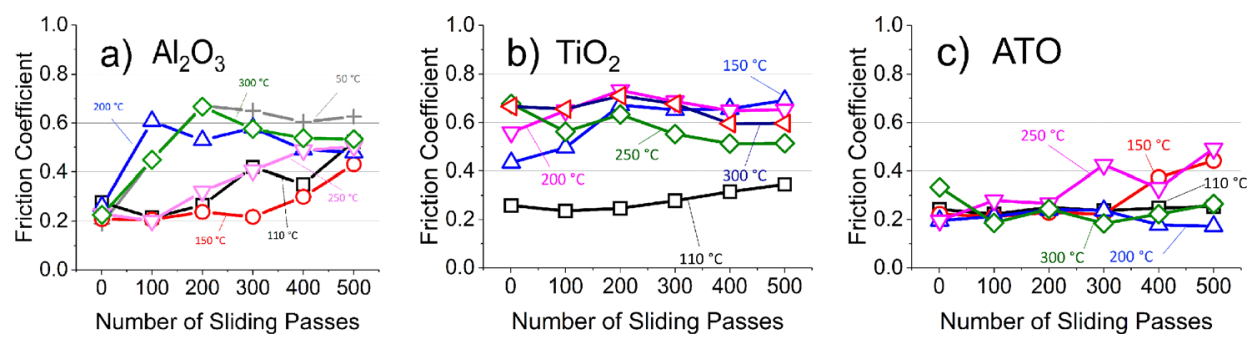

FIg. 3. (Color online) Friction of $\mathrm{Al}_{2} \mathrm{O}_{3}, \mathrm{TiO}_{2}$ and ATO: The friction coefficient of $\mathrm{ALD}$ deposited at different temperatures: (a) $\mathrm{Al}_{2} \mathrm{O}_{3}$ films ( $300 \mathrm{~nm}$ thick except $100 \mathrm{~nm}$ and $50^{\circ} \mathrm{C}$ sample), (b) $\mathrm{TiO}_{2}$ films ( $100 \mathrm{~nm}$ thick) and (c) ATO nanolaminate coatings ( $100 \mathrm{~nm}$ thick). The friction was determined in reciprocative sliding tests carried out in stepwise manner with MCT test device with the $0.3 \mathrm{~N}$ normal load, $0.01 \mathrm{~m} \mathrm{~s}^{-1}$ sliding speed and 500 sliding passes for a total of $5 \mathrm{~m}$ sliding distance. 

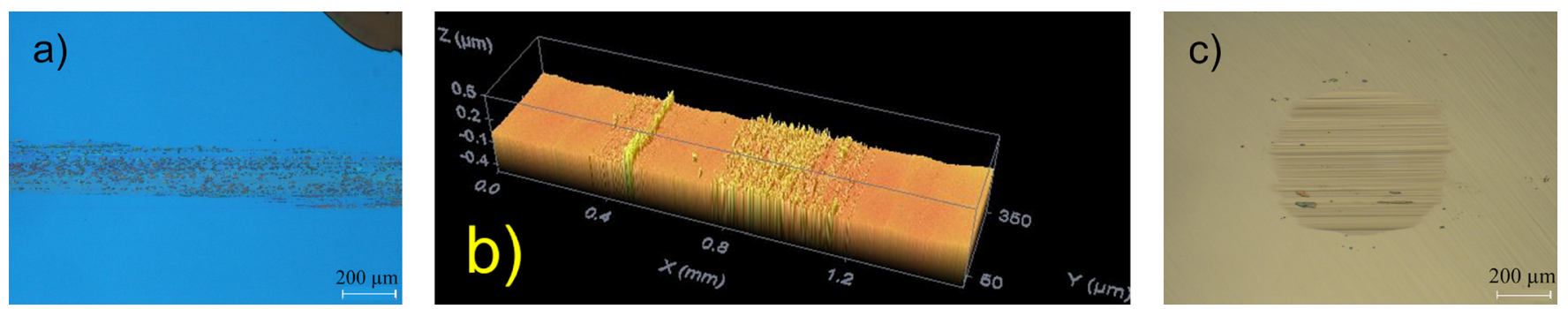

FIG. 4. (Color online) Wear surfaces of $\mathrm{Al}_{2} \mathrm{O}_{3}$ and $\mathrm{Si}$ : (a) The wear track on the $\mathrm{ALD} \mathrm{Al}_{2} \mathrm{O}_{3}$ film $\left(300 \mathrm{~nm}\right.$ thick, deposition temperature $300^{\circ} \mathrm{C}$ ), (b) the $3 \mathrm{D}$ profile of the wear track on the $\mathrm{Al}_{2} \mathrm{O}_{3}$ film, and (c) the wear surface of the silicon pin sliding against $\mathrm{ALD} \mathrm{Al}_{2} \mathrm{O}_{3}$ film after the reciprocating sliding test. The reciprocative sliding test was carried out with $0.3 \mathrm{~N}$ normal load, $0.01 \mathrm{~m} \mathrm{~s}^{-1}$ sliding speed and 500 sliding passes equivalent to $5 \mathrm{~m}$ sliding distance.

ATO films providing higher friction, generation of tribolayer on the coating surface and wear of silicon pin was observed.

\section{Continuous reciprocative sliding tests}

a. Tests with $5 \mathrm{~m}$ sliding distance. Selected samples were tested also for long-term durability and tribological performance with continuous reciprocating sliding tests. These tests were carried out with the tribometer 1 device which provided more accurate friction data as compared to MCT device when low normal loads were used. The friction coefficients, with $\mathrm{Si}$ pins acting as the counter material against the ALD coatings, are presented in Table III for $0.01,1$, and $5 \mathrm{~m}$ sliding. For the coatings providing low friction in the $5 \mathrm{~m}$ sliding tests, also longer $20 \mathrm{~m}$ sliding tests were carried out.

The friction evolution graphs from the continuous sliding tests of $\mathrm{Al}_{2} \mathrm{O}_{3}, \mathrm{TiO}_{2}$, ATO, DLC, and uncoated silicon reference are shown in Figs. 7(a)-7(d). The friction of $\mathrm{Al}_{2} \mathrm{O}_{3}$ deposited at 50 and $300{ }^{\circ} \mathrm{C}$ was low in the beginning of the test, but increased during the test reaching friction values around 0.5 [Fig. 7(a)]. This performance was comparable to previously presented data obtained from stepwise reciprocating sliding tests. The $\mathrm{TiO}_{2}$ deposited at 110 and $300^{\circ} \mathrm{C}$ also showed similar trend as compared to data obtained in the stepwise reciprocating sliding tests. $\mathrm{TiO}_{2}$ deposited at $110^{\circ} \mathrm{C}$ had low friction up to $3 \mathrm{~m}$ sliding, but increased in the end of the test to friction coefficient value of 0.45 [Fig. 7(b)]. $\mathrm{TiO}_{2}$ deposited at $300{ }^{\circ} \mathrm{C}$ had high friction during the whole test duration. The ATO films deposited at 110 and $250{ }^{\circ} \mathrm{C}$ provided low friction performance with some variation [Fig. 7(c)]. Also, in the case of $250^{\circ} \mathrm{C}$ ATO, friction coefficient increased to 0.45 in the end of $5 \mathrm{~m}$ sliding.

The friction data of the reference measurements, silicon pin sliding against uncoated $\langle 100\rangle$ silicon wafer and DLC (a$\mathrm{C}: \mathrm{H})$ coated silicon, are presented as reference [Fig. 7(d)]. The reference silicon wafer had low values of about 0.25 , which increased and stabilized in the range 0.5 to 0.7 during the $5 \mathrm{~m}$ sliding test. A noticeable wear of the Si pin was observed during the test. The DLC coating had a stable friction coefficient at a low value of $0.1-0.2$. The contact surface of the DLC film was smooth with no visible tribolayer formation. Also, the wear surface of the silicon pin was smooth with low wear. Overall, the DLC reference provided the lowest friction performance of all tests.

b. Tests with $20 \mathrm{~m}$ sliding distance. In the continuous sliding tests, the most promising coatings with a low friction coefficient at the end of the test were ATO, TiN, TiAlCN, and $\mathrm{NbN}$. The $20 \mathrm{~m}$ sliding tests were carried out for these coatings in order to observe the durability of the coatings in sliding contact. The friction evolution during the $20 \mathrm{~m}$ sliding for these four coatings is presented in Fig. 8.

The friction coefficient of ATO was low in the beginning of the $20 \mathrm{~m}$ test, but increased after about $5 \mathrm{~m}$ sliding to the level of 0.5 [Fig. 8(a)]. The TiN coating provided lower friction coefficient throughout the $20 \mathrm{~m}$ sliding in the range $0.2-0.3$ [Fig. 8(a)]. The TiAlCN showed friction values between 0.3 and 0.4 from the start until about $10 \mathrm{~m}$ sliding. After $10 \mathrm{~m}$ sliding, the friction increased close to 0.6. The coating seemed to wear during the test and toward the end of
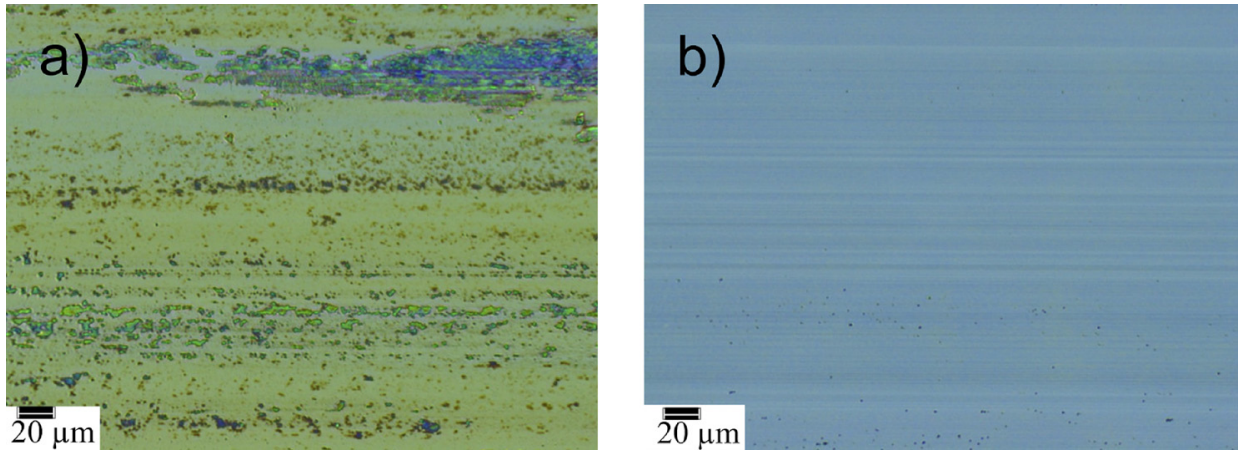

FIg. 5. (Color online) Wear tracks of $\mathrm{TiO}_{2}$ coating: The wear track on the (a) $\mathrm{TiO}_{2}$ film $\left(100 \mathrm{~nm}\right.$ thick, deposition temperature $\left.300^{\circ} \mathrm{C}\right)$ and $(\mathrm{b}) \mathrm{TiO}{ }_{2}$ film $\left(100 \mathrm{~nm}\right.$ thick, deposition temperature $110^{\circ} \mathrm{C}$ ). The $0.3 \mathrm{~N}$ normal load and $0.01 \mathrm{~m} \mathrm{~s}^{-1}$ sliding speed and $5 \mathrm{~m}$ sliding distance was used in the MCT tests. 

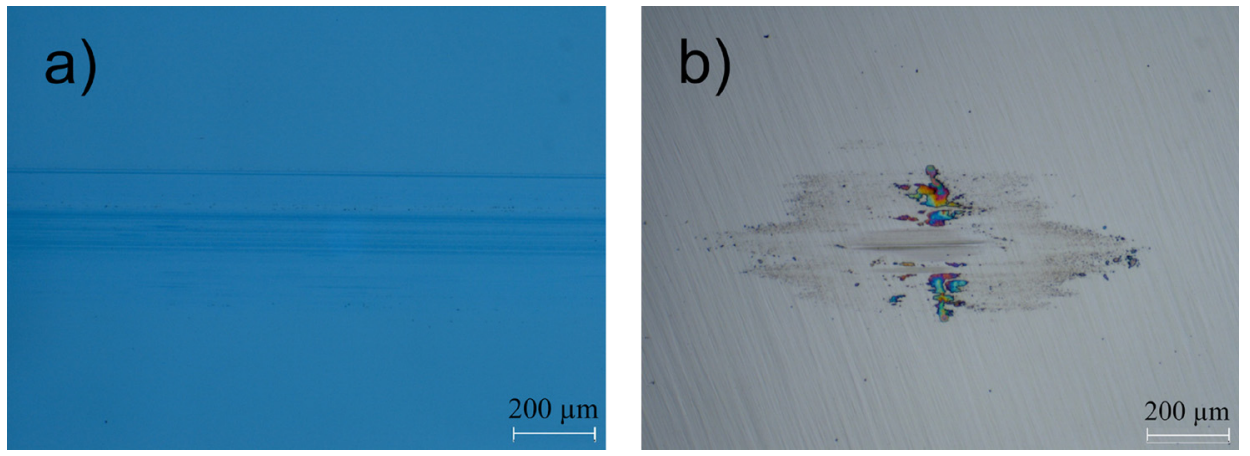

FIG. 6. (Color online) Wear surfaces of ATO and Si: (a) The wear track on the ATO nanolaminate $\left(100 \mathrm{~nm}\right.$ thick, deposition temperature $\left.110^{\circ} \mathrm{C}\right)$ and (b) the wear surface of the silicon pin sliding against ATO nanolaminate. The $0.3 \mathrm{~N}$ normal load and $0.01 \mathrm{~m} \mathrm{~s}^{-1}$ sliding speed and $5 \mathrm{~m}$ sliding distance was used in the tests.

$20 \mathrm{~m}$ sliding test, the coating was completely worn through down to the Si substrate [Fig. 9(a)]. As a result, only slight amount of wear was observed on the Si pin. There was a tribolayer formed on top of the Si pin as observed in Fig. 9(b). The tribolayer formed on the Si pin was analyzed by SEM and EDS. The analysis showed that the tribolayer consisted mostly of oxidized coating material accumulated on the sliding surface [Fig. 9(c)]. The friction values of the ALD NbN coating remained low, in the range $0.2-0.4$, in the $5 \mathrm{~m}$ sliding tests and also throughout the $20 \mathrm{~m}$ sliding distance tests. The $\mathrm{NbN}$ had more stable friction performance than the PEALD TiN coating. On the $\mathrm{NbN}$ surface, no tribolayer was observed [Fig. 10(a)], but the Si pin contact surface had a tribolayer and also loose wear debris around the contact area [Fig. 10(b)]. As a result of the tribolayer, the wear of the Si pin was low.
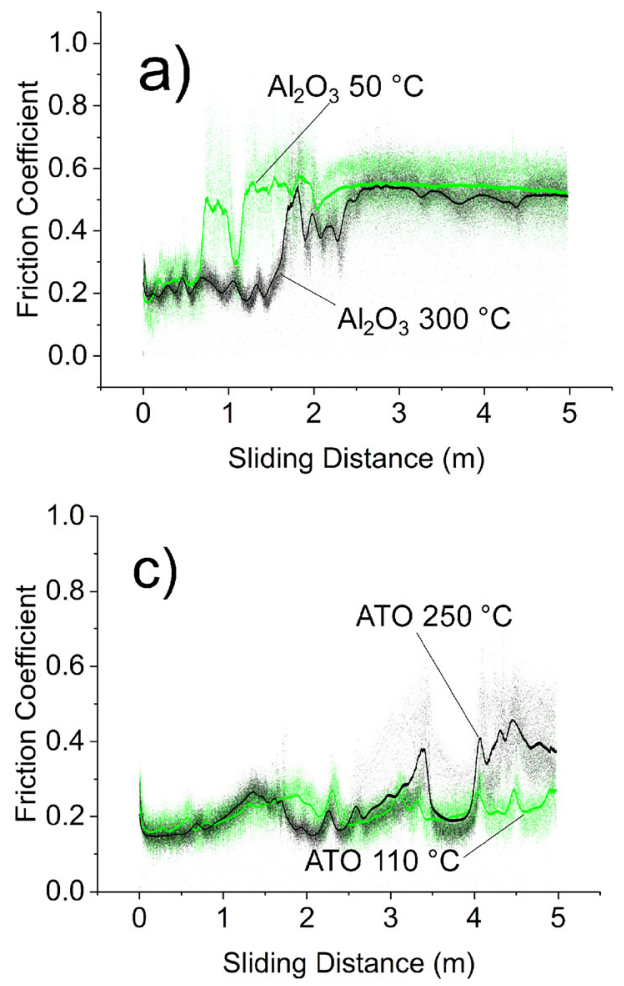

In Figs. 7 and 8, the actual variation of friction coefficient during the tests is presented combined with the moving average of friction. The variation during tests described the stability of the silicon-coating contact: the lower the variation, the more stable is the tribological performance of the coating against silicon. Considering the friction variation, $\mathrm{NbN}$ and TiN showed the most favorable performance in the $20 \mathrm{~m}$ test.

\section{Wear of ALD films and silicon counterparts}

The wear of the silicon pin and of the counterpart was measured after the tests. The results are shown in Table IV. Typically, silicon pin experienced high wear, particularly in the case of $\mathrm{Al}_{2} \mathrm{O}_{3}$ and $\mathrm{TiO}_{2}$ coatings. The $\mathrm{Si}$ pin wear against ATO films was lower than against $\mathrm{Al}_{2} \mathrm{O}_{3}$ and $\mathrm{TiO}_{2}$. The pin
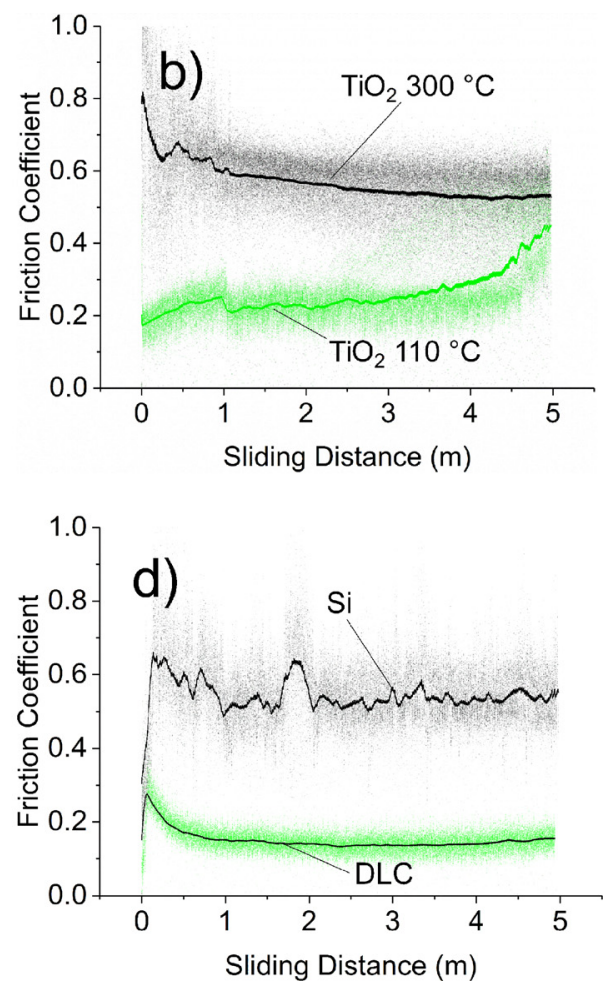

FIG. 7. (Color online) Friction of $\mathrm{Al}_{2} \mathrm{O}_{3}, \mathrm{TiO}_{2}, \mathrm{ATO}, \mathrm{DLC}$ and Si: The friction coefficient evolution as scatter graphs (with trend line) of continuous reciprocative sliding tests with $0.3 \mathrm{~N}$ normal load and $0.01 \mathrm{~m} \mathrm{~s}^{-1}$ sliding speed with sliding distance of $5 \mathrm{~m}$. (a) $\mathrm{ALD}_{2} \mathrm{O}_{2} \mathrm{O}_{3} \mathrm{coatings}\left(100 \mathrm{~nm} / 50{ }^{\circ} \mathrm{C}\right.$ and $300 \mathrm{~nm} /$ $\left.300^{\circ} \mathrm{C}\right)$, (b) $\mathrm{ALD} \mathrm{TiO}_{2}$ coatings $\left(100 \mathrm{~nm} / 300^{\circ} \mathrm{C}\right.$ and $\left.100 \mathrm{~nm} / 110^{\circ} \mathrm{C}\right)$, (c) ALD ATO nanolaminate coatings $\left(100 \mathrm{~nm} / 110^{\circ} \mathrm{C}\right.$ and $\left.100 \mathrm{~nm} / 250{ }^{\circ} \mathrm{C}\right)$ as well as $(\mathrm{d})$ $\mathrm{Si}$ and DLC coatings. 

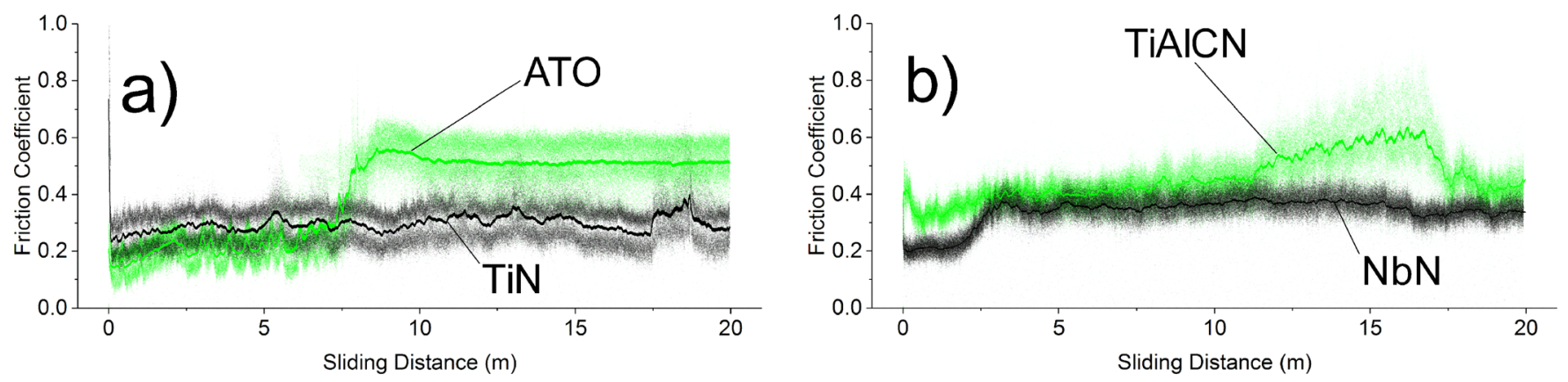

FIG. 8. (Color online) Friction of ATO, TiN, TiAlCN and NbN: The friction coefficient evolution as scatter graphs (with trend line) of continuous reciprocative sliding tests with $0.3 \mathrm{~N}$ normal load and $0.01 \mathrm{~m} \mathrm{~s}^{-1}$ sliding speed and sliding distance of $20 \mathrm{~m}$. (a) ALD ATO nanolaminate $\left(100 \mathrm{~nm} / 110^{\circ} \mathrm{C}\right)$ and PEALD TiN coating $\left(100 \mathrm{~nm} / 300^{\circ} \mathrm{C}\right)$, and b) $\operatorname{ALD~TiAlCN}\left(100 \mathrm{~nm} / 400^{\circ} \mathrm{C}\right)$ and $\operatorname{ALD~NbN}\left(100 \mathrm{~nm} / 400^{\circ} \mathrm{C}\right)$ coating.

wear against the PEALD TiN, TiAlCN, NbN, and DLC films was below the detection limit.

The wear determination of the ALD films was, in most cases, not possible due to the tribolayer formation or low wear of the coating. The wear rates could be determined for the TiAlCN, NbN, and PEALD TiN films. The TiAlCN had high wear since it was worn throughout the coating [Fig. 9(a)]. The NbN coating had the lowest wear rate [Fig. 10(a)].

\section{DISCUSSION}

Friction coefficient is not an intrinsic material parameter but a system parameter. This was clearly observed in the tests carried out with the silicon counter surface sliding against ALD films on silicon. For the friction and wear experiments to succeed, adhesion between $\mathrm{Si}$ substrate and the coating needs to be good. For $\mathrm{Al}_{2} \mathrm{O}_{3}, \mathrm{TiO}_{2}$ and ATO nanolaminate coatings adhesion was good as described in a previous work. ${ }^{48}$ However, some coating delamination was observed for the PEALD TiN coating during the tests, indicating inadequate adhesion.

The main influencing phenomenon influencing the friction performance was observed to be the tribochemical interaction between silicon and the coating material. Silicon based tribolayer formed on the coating surface generally resulted in a high friction coefficient, such as in Fig. 3 for the $\mathrm{Al}_{2} \mathrm{O}_{3}$ films and $\mathrm{TiO}_{2}$ films deposited at high temperatures. The friction increased during sliding up to values 0.5 and even 0.7, which is in the same range as for the silicon against the silicon contact.

The friction and wear values presented in this paper can be compared to other basic tribological contact pairs. ${ }^{49} \mathrm{~A}$ relatively high friction coefficient is typically generated in dry steel against steel contact, with friction coefficient being in the range from 0.7 to $0.9 .{ }^{50}$ An example of a low friction coefficient value is the contact between DLC and steel with friction coefficient being in the range $0.1-0.2$ and even lower values down to 0.002 , depending on the coating properties and the test conditions. ${ }^{31,32}$

For the $\mathrm{ALD} \mathrm{Al}_{2} \mathrm{O}_{3}$, sliding against silicon, the friction coefficient was about 0.2 in the beginning of the tests but soon increased to values up to 0.5 . The increase in friction was connected to the formation of the tribolayer on the wear track of the $\mathrm{Al}_{2} \mathrm{O}_{3}$ film visible in the 3D profile presented in Fig. 4(b). The tribolayer consisted of oxidized silicon since the silicon pin experienced high wear during the tests. The $\mathrm{Al}_{2} \mathrm{O}_{3}$ films deposited at temperatures 110,150 , and $250^{\circ} \mathrm{C}$ could provide lower friction values for a longer period of sliding compared to films deposited at 200 and $300^{\circ} \mathrm{C}$. As reported earlier by Ylivaara et al., ${ }^{34}$ the ALD films deposited at low temperatures contain hydrogen which could enhance the low friction performance in the beginning of the test. However, in all cases, the friction increased to values around 0.5 toward the end of the test. High friction and tribolayer formation was also observed in the case of low temperature $\mathrm{ALD} \mathrm{Al}_{2} \mathrm{O}_{3}$ coating deposited at $50{ }^{\circ} \mathrm{C}$, although a published patent ${ }^{28}$ suggests low friction
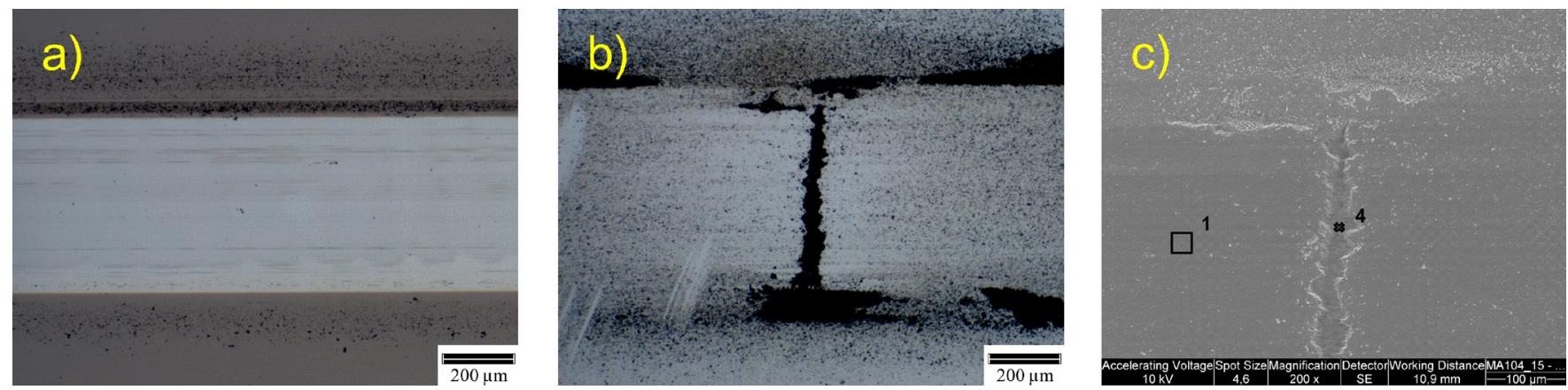

FIg. 9. (Color online) Wear surface of TiAlCN and Si: (a) The wear track on TiAlCN coating $\left(100 \mathrm{~nm} / 400^{\circ} \mathrm{C}\right)$, (b) wear surface of the Si counterpart sliding against TiAlCN, and (c) the SEM image of the wear surface and the tribolayer on the Si pin that was sliding against the TiAlCN coating for $20 \mathrm{~m}$. Point 1 consists of 0.88 (at. \%) C, $2.01 \mathrm{O}$ and $97.10 \mathrm{Si}$. Point 4 consists of 1.44 (at. \%) C, 7.52 N, 63.21 O, $0.96 \mathrm{Al}, 2.15 \mathrm{Si}, 2.12 \mathrm{Cl}$ and $22.60 \mathrm{Ti}$. The chloride originates as an impurity from the ALD process. 

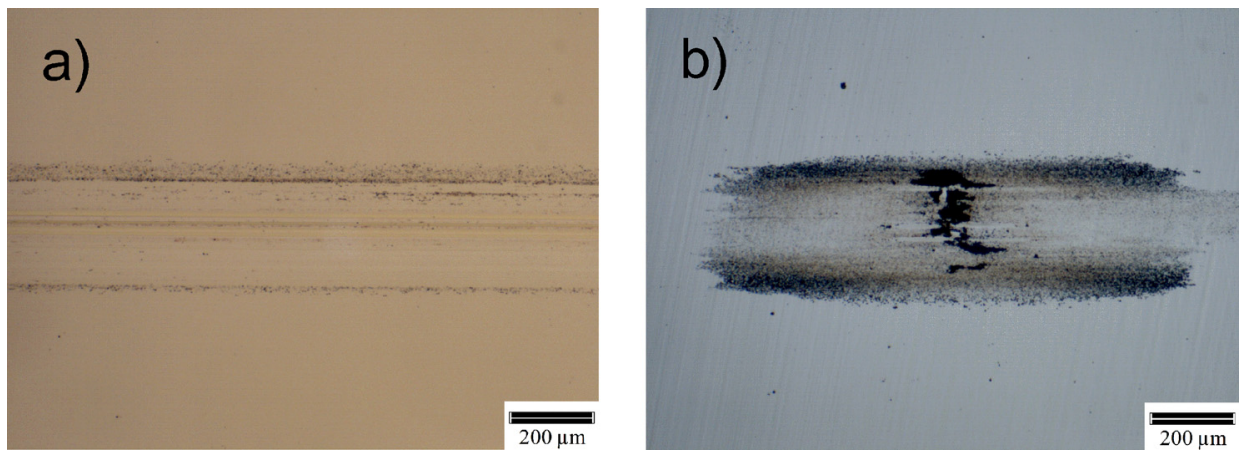

Fig. 10. (Color online) Wear surface of $\mathrm{NbN}$ and $\mathrm{Si}$ : (a) The wear track on $\mathrm{NbN}\left(100 \mathrm{~nm} / 400^{\circ} \mathrm{C}\right)$, and (b) the wear surface of the Si counterpart sliding against $\mathrm{NbN}$ after the reciprocative sliding with $0.3 \mathrm{~N}$ normal load, sliding velocity of $0.01 \mathrm{~m} \mathrm{~s}^{-1}$ and sliding distance of $20 \mathrm{~m}$.

performance of such films. Based on the tribological test results, the friction performance of $\mathrm{ALD} \mathrm{Al}_{2} \mathrm{O}_{3}$ films was defined by the tribolayer formation on the coating contact surface and the time required for the tribofilm to evolve.

The deposition temperature of ALD $\mathrm{TiO}_{2}$ influenced the structure of the coating material, since films deposited at $200{ }^{\circ} \mathrm{C}$ and above had a crystalline structure, which increased the surface roughness. The crystallinity and roughness caused the high initial friction values, after which the values leveled down, but still remained between 0.5 and 0.7. ALD $\mathrm{TiO}_{2}$ deposited at low temperature $\left(110^{\circ} \mathrm{C}\right)$ had amorphous structure providing lower friction performance in the range 0.3 to 0.4. In the sliding tests, only a thin tribolayer was formed on the coating wear track (Fig. 5). According to the results of Ylivaara et al. ${ }^{35}$ concerning $\mathrm{TiO}_{2}$ and $\mathrm{Al}_{2} \mathrm{O}_{3}-\mathrm{TiO}_{2}$ nanolaminates, the coatings deposited at low temperature had higher amount of impurities, such as chlorine and hydrogen. Particularly, the hydrogen content might have had a beneficial effect reducing the friction. However, also in this case, the friction was showing an increasing trend toward the end of the $5 \mathrm{~m}$ sliding tests. It is noteworthy that the silicon pin wear rate depended on the $\mathrm{TiO}_{2}$ growth temperature; the higher the temperature, the faster the wear.

When the ALD ATO nanolaminates, consisting of $\mathrm{Al}_{2} \mathrm{O}_{3}$ and $\mathrm{TiO}_{2}$ lamellas, were sliding against silicon, little or no tribolayer formed on the surface of the coatings (Fig. 6). Friction was low compared to single material $\mathrm{ALD} \mathrm{Al}_{2} \mathrm{O}_{3}$ and $\mathrm{TiO}_{2}$ films. In this case, some tribolayer was formed on the contact surface of silicon. The nanolaminate structure, thus, seemed to have a beneficial synergy providing lower friction performance in most cases during the $5 \mathrm{~m}$ sliding tests. However, in some cases, the nanolaminate coatings showed increasing values toward the end of the $5 \mathrm{~m}$ sliding test and during the $20 \mathrm{~m}$ sliding test a tribolayer, increasing the friction coefficient above 0.5 , was formed even for the most promising ATO coatings. In the $20 \mathrm{~m}$ sliding test, the increase in friction after $5 \mathrm{~m}$ is probably due to the bilayer structure of ATO nanolaminate. The outermost $2 \mathrm{~nm}$ thick $\mathrm{Al}_{2} \mathrm{O}_{3}$ layer might have worn out exposing the $\mathrm{TiO}_{2}$ into the contact.

The ALD coatings prone to generate a tribolayer on the coating surface thus increasing the friction were $\mathrm{Al}_{2} \mathrm{O}_{3}$, $\mathrm{TiO}_{2}$, and ATO nanolaminate. The silicon pin was typically worn forming of a tribolayer consisting of silicon oxide on top of the coating surface. Especially in the case of $\mathrm{TiO}_{2}$, the wear of Si pin was significant due to the deposition temperature of the coating being $300{ }^{\circ} \mathrm{C}$. The increased deposition temperature caused the $\mathrm{TiO}_{2}$ to grow as anatase, with higher coating hardness and increased surface roughness. Surface roughness values increased from about $\mathrm{Ra} 0.5 \mathrm{~nm}$ to $\mathrm{Ra}$ $4.3 \mathrm{~nm}$ as measured with XRR. ${ }^{51}$ The Si pin wear was significantly increased due to coating hardness and high surface roughness compared to amorphous $\mathrm{TiO}_{2}$ (Table IV). The contact temperature was increased due to friction increase during sliding, further enhancing the oxide formation. Similar kind of tribolayer was formed when the bulk silicon pin was sliding against the uncoated silicon wafer, providing friction coefficient of 0.7 . This is in the same range as the friction coefficient of many ALD films sliding against silicon. When a tribolayer was formed on the coating surface sliding against silicon pin, the contact occurred actually between similar materials ( $\mathrm{Si}$ to $\mathrm{Si}$ ) and due to this similarity the friction increased reaching similar friction values to silicon against silicon contact.

TABLE IV. Wear rates of the silicon pins and the ALD and reference coatings after $5 \mathrm{~m}$ continuous reciprocative sliding. The normal load was $0.3 \mathrm{~N}$ and the sliding velocity $0.01 \mathrm{~ms}^{-1}$.

\begin{tabular}{|c|c|c|}
\hline Counter material & $\begin{array}{l}\text { Si pin wear rate } \\
\left(10^{-6} \mathrm{~mm}^{3} / \mathrm{N} \mathrm{m}\right)\end{array}$ & $\begin{array}{c}\text { ALD coating } \\
\text { wear rate } \\
\left(10^{-6} \mathrm{~mm}^{3} / \mathrm{N} \mathrm{m}\right)\end{array}$ \\
\hline Si reference & 970 & a \\
\hline $100 \mathrm{~nm} 50^{\circ} \mathrm{C} \mathrm{Al}_{2} \mathrm{O}_{3}$ & 850 & a \\
\hline $300 \mathrm{~nm} 300^{\circ} \mathrm{C} \mathrm{Al}_{2} \mathrm{O}_{3}$ & 790 & a \\
\hline $100 \mathrm{~nm} 110^{\circ} \mathrm{C} \mathrm{TiO}_{2}$ & 120 & a \\
\hline $100 \mathrm{~nm} 150{ }^{\circ} \mathrm{C} \mathrm{TiO}_{2}$ & 410 & a \\
\hline $100 \mathrm{~nm} 300^{\circ} \mathrm{C} \mathrm{TiO}_{2}$ & 1900 & a \\
\hline $100 \mathrm{~nm} 110^{\circ} \mathrm{C}$ ATO & 6 & $\mathrm{~b}$ \\
\hline $100 \mathrm{~nm} 150^{\circ} \mathrm{C}$ ATO & 3 & a \\
\hline $100 \mathrm{~nm} 250^{\circ} \mathrm{C}$ ATO & 140 & a \\
\hline $100 \mathrm{~nm} 300^{\circ} \mathrm{C}$ ATO & 3 & a \\
\hline $100 \mathrm{~nm} 300^{\circ} \mathrm{C} \mathrm{PEALD} \mathrm{TiN}$ & $<0.05$ & 8 \\
\hline $100 \mathrm{~nm} 400^{\circ} \mathrm{C}$ TiAlCN & $<0.05$ & 70 \\
\hline $100 \mathrm{~nm} 400^{\circ} \mathrm{C} \mathrm{NbN}$ & $<0.05$ & 2 \\
\hline $85 \mathrm{~nm}$ DLC & $<0.05$ & $\mathrm{~b}$ \\
\hline
\end{tabular}

${ }^{a}$ Not measurable due to tribolayer formation.

${ }^{\mathrm{b}}$ Too low wear to give a value. 
For the ALD NbN coating, the tribolayer was formed on the silicon pin surface and no layer formation was observed on $\mathrm{NbN}$ coating. This behavior provided low friction performance in the range of 0.3 to 0.4 in the $5 \mathrm{~m}$ sliding tests. Also, the PEALD TiN film had the low friction value of 0.3 in the end of the sliding tests. Some measurable coating wear was detected on both TiN and NbN films with more occurring on $\mathrm{NbN}$ than TiN (Table IV).

The ALD TiAlCN coatings had similar tribolayer formation on the silicon pin as $\mathrm{NbN}$, but the friction of TiAlCN coating reached values in the range of 0.4 to 0.6 in the end of the tests. The wear of the TiAlCN coating was high, since after $5 \mathrm{~m}$ sliding test, the coating was locally worn through, and after $20 \mathrm{~m}$ sliding, most of the coating was worn out. The SEM-EDS analyses of the tribolayer formed on the silicon pin proved that the layer consisted mostly of oxidized coating material, which showed the transfer of worn coating material onto the silicon surface.

In the long-term performance of $20 \mathrm{~m}$ sliding tests, PEALD TiN and ALD NbN had the lowest friction around $0.3-0.35$ as presented in Fig. 8. In this case, the coatings experienced some wear and the tribolayer was formed on the silicon pin surface instead of the coating surface with a low amount of pin wear. Taking the adhesion problem of PEALD TiN into account, the $\mathrm{NbN}$ coating provided the best tribological performance with low friction and wear in the $20 \mathrm{~m}$ sliding tests in this study.

When comparing the friction performance of ALD films with the a-C:H type DLC coating, there was a clear difference in the performance. In the beginning of the tests, the friction of DLC films was between 0.2 and 0.3 , but as the sliding proceeded, the friction was reduced and the DLC films provided low friction coefficient around 0.1 during $5 \mathrm{~m}$ sliding tests. No tribolayer formation was observed in this case. This friction performance is typical for the a-C:H coatings, and the results were in line with the published ones for a-C:H films sliding against different counterpart materials. ${ }^{52}$

The low and stable friction performance is beneficial in most applications. For MEMS devices, besides DLC coating, ALD NbN and PEALD TiN could provide low friction performance. The wear of the Si pin and the thin film greatly influence the usability of the material pair in MEMS environment. The film materials, such as a-C:H, ALD NbN, and PEALD TiN, that have the wear rate of the pin and the film under $10^{-6}$ $\mathrm{mm}^{3} / \mathrm{Nm}$ are more likely to provide satisfactory performance.

\section{CONCLUSIONS}

Tribological tests were carried out with silicon counterpart sliding against various ALD thin films, simulating the contacts occurring in the MEMS devices. In the tribological tests, the formation of the tribolayer in the contact area was the dominating phenomenon for friction and wear performance of ALD films. For the $\mathrm{Al}_{2} \mathrm{O}_{3}, \mathrm{TiO}_{2}$, and ATO nanolaminate coatings, the tribolayer formation was observed with friction values stabilizing between 0.5 and 0.7 . The TiAlCN film had friction values in the range of $0.4-0.6$ in the end of the test and increased wear occurred on the coating. The
$\mathrm{NbN}$ and PEALD TiN coatings had lower friction in the range of 0.3-0.4. TiN suffered to some extent from wear and inadequate adhesion. The $\mathrm{NbN}$ film provided the most favorable friction and wear performance of the ALD films, yet lower friction was measured for the DLC a-C:H coating.

\section{ACKNOWLEDGMENTS}

The authors are grateful for Tekes-the Finnish Funding Agency for Innovation, ASM Microchemistry Oy, Beneq Oy, Murata Electronics Oy, Picosun Oy, Okmetic Oyj, and Oxford Instruments Analytical Oy for funding this work carried out in MECHALD project. Special thanks to Okmetic Oyj for providing bulk silicon for manufacturing the silicon pins used in the tribological experiments. Simo Varjus and Saima Ali are acknowledged for their contribution concerning tribological measurements and XRR, respectively. This work is linked to the Finnish Centres of Excellence in Atomic Layer Deposition (Reference No. 251220). L.K. designed the tribological experiments together with H.R. and performed the tribological experiments together with A.V. under supervision of H.R. R.L.P. and O.M.E.Y. were responsible for designing the ALD. sample series. O.M.E.Y. made the $\mathrm{Al}_{2} \mathrm{O}_{3}$, $\mathrm{TiO}_{2}$ and ATO growth at VTT. V.R. made the $\mathrm{NbN}$ growth at Aalto University; J.M. and T.S. made the $50^{\circ} \mathrm{C} \mathrm{Al}_{2} \mathrm{O}_{3}$ growth at University of Jyväskylä; X.L. and E.H. made nanoindentation measurements under supervision of S.P.H.; M.B. made the PEALD TiN growth; and M.T. made the TiAlCN growth. L.K. interpreted the data and wrote the literature review under supervision of H.R. and R.L.P. S.S. made XRR measurements and analysis under supervision of H.L. Co-authors discussed the results with L.K. and commented on the manuscript at all stages.

\footnotetext{
${ }^{1}$ R. L. Puurunen, J. Appl. Phys. 97, 121301 (2005).

${ }^{2}$ M. Ritala and M. Leskelä, Handbook of Thin Film Materials, edited by $\mathrm{H}$. S. Nalwa (Academic, San Diego, CA, 2001), Vol. 1, pp. 103-159.

${ }^{3}$ S. M. George, Chem. Rev. 110, 111 (2010).

${ }^{4}$ E. Ahvenniemi et al., J. Vac. Sci. Technol., A. 35, 010801 (2017).

${ }^{5}$ R. L. Puurunen, H. Kattelus, and T. Suntola, Handbook of Silicon Based MEMs Materials and Technologies, edited by V. Lindroos, M. Tilli, A. Lehto, and T. Motooka, (Elsevier, Oxford, 2010), pp. 433-446.

${ }^{6}$ T. M. Mayer, J. W. Elam, S. M. George, P. G. Kotula, and R. S. Goeke, Appl. Phys. Lett. 82, 2883 (2003).

${ }^{7}$ N. D. Hoivik, J. W. Elam, R. J. Linderman, V. M. Bright, S. M. George, and Y. C. Lee, Sens. Actuator, A 103, 100 (2003).

${ }^{8}$ C. F. Herrmann, F. W. DelRio, D. C. Miller, S. M. George, V. M. Bright, J. L. Ebel, R. E. Strawser, R. Cortez, and K. D. Leedy, Sens. Actuator, A 135, 262 (2007).

${ }^{9}$ T. W. Scharf, S. V. Prasad, T. M. Mayer, R. S. Goeke, and M. T. Dugger, J. Mater. Res. 19, 3443 (2004).

${ }^{10}$ J. Kyynäräinen et al., Sens. Lett. 5, 126 (2007).

${ }^{11}$ R. L. Puurunen, J. Saarilahti, and H. Kattelus, ECS Trans. 11, 3 (2007).

${ }^{12}$ M. Blomberg, H. Kattelus, and A. Miranto, Sens. Actuator, A 162, 184 (2010).

${ }^{13}$ A. Rissanen, U. Kantojärvi, M. Blomberg, J. Antila, and S. Eränen, Sens. Actuator, A 182, 130 (2012).

${ }^{14}$ R. L. Puurunen et al., Sens. Actuator, A 188, 240 (2012).

${ }^{15}$ B. D. Davidson, D. Seghete, S. M. George, and V. M. Bright, Sens. Actuator, A 166, 269 (2011).

${ }^{16}$ K. Petersen, Proc. IEEE 70, 420 (1982).

${ }^{17}$ K. E. Bean and P. S. Gleim, Proc. IEEE 57, 1469 (1969).

${ }^{18} \mathrm{Q}$. Chen and G. Carman, "Microscale tribology (friction) measurement and influence of crystal orientation and fabrication process," in
} 
Proceedings of the 13th Annual International Conference on Micro Electro Mechanical System (2000), pp. 657-661.

${ }^{19}$ P. Stempflé and J. Takadoum, Tribol. Int. 48, 35 (2012).

${ }^{20}$ D. J. Fonseca and M. Sequera, Int. J. Qual. Stat. Reliab. 2011, 820243 (2011).

${ }^{21}$ Y. Huang, A. S. S. Vasan, R. Doaraiswami, M. Osterman, and M. Pecht, IEEE Trans. Device Mater. Reliab. 12, 482 (2012).

${ }^{22}$ Z. Chai, X. Lu, and D. He, Surf. Coat. Technol. 207, 361 (2012).

${ }^{23}$ V. Ageh, H. Mohseni, and T. W. Scharf, Surf. Coat. Technol. 237, 241 (2013).

${ }^{24}$ V. Ageh, H. Mohseni, and T. W. Scharf, Surf. Coat. Technol. 241, 112 (2013).

${ }^{25}$ H. Mohseni and T. W. Scharf, Wear 332-333, 1303 (2015).

${ }^{26}$ T. W. Scharf, S. V. Prasad, M. T. Dugger, P. G. Kotula, R. S. Goeke, and R. K. Grubbs, Acta Mater. 54, 4731 (2006).

${ }^{27}$ C. Cannaro, J. Chinn, and B. Kobrin, "Exceptional wear resistance of MEMS devices coated with carbon-doped alumina films," in Proceedings of Solid-State Sensors, Actuators and Microsystems Conference, Lyon, France (2007), pp. 1319-1320.

${ }^{28}$ B. Kobrin, R. Nowak, and J. D. Chinn, "Wear-resistant, carbon-doped metal oxide coatings for MEMS and nanoimprint lithography," U.S. patent US20100068489A1 (18 March 2010).

${ }^{29}$ A. Erdemir and C. Donnet, J. Phys. D: Appl. Phys. 39, 331 (2006).

${ }^{30} \mathrm{C}$. Donnet and A. Erdemir, Tribology of Diamond-Like Carbon Films-Fundamentals and Applications (Springer, New York, 2008), p. 664.

${ }^{31}$ H. Ronkainen, S. Varjus, J. Koskinen, and K. Holmberg, Wear 249, 260 (2001).

${ }^{32} \mathrm{H}$. Ronkainen and K. Holmberg, "Environmental and thermal effects on the tribological performance of DLC coatings," in Tribology of DiamondLike Carbon Films, edited by C. Donnet and A. Erdemir (Springer, New York, 2008), pp. 155-200.

${ }^{33} \mathrm{~W}$. Kern, Handbook of Semiconductor Wafer Cleaning Technology-Science, Technology, and Applications, edited by W. Kern (William Andrew/Noyes, Westwood, NJ, 1993), pp. 1-67.
${ }^{34}$ O. M. E. Ylivaara et al., Thin Solid Films 552, 124 (2014).

${ }^{35}$ O. M. E. Ylivaara et al., J. Vac. Sci. Techol., A. 35, $01 \mathrm{~B} 105$ (2017).

${ }^{36} \mathrm{~V}$. Rontu, "Atomic layer deposition of niobium nitride thin films," Master's thesis (Aalto University, Espoo, Finland, 2014).

${ }^{37}$ K. N. Stoev and K. Sakurai, Spectrochim. Acta, B 54, 41 (1999).

${ }^{38}$ S. Sintonen, A. Saima, O. M. E. Ylivaara, R. L. Puurunen, and H. Lipsanen, J. Vac. Sci. Technol., A 32, 01A111 (2014).

${ }^{39}$ L. G. Parratt, Phys. Rev. 95, 359 (1954).

${ }^{40}$ W. C. Oliver and G. M. Pharr, J. Mater. Res. 7, 1564 (1992).

${ }^{41}$ D. C. Miller, R. R. Foster, S.-H. Jen, J. A. Bertrand, S. J. Cunningham, A. S. Morris, Y.-C. Lee, S. M. George, and M. L. Dunn, Sens. Actuator, A 164, 58 (2010).

${ }^{42}$ J. F. Shackelford, Y.-H. Han, S. Kim, and S.-H. Kwon, CRC Materials Science and Engineering Handbook, 4th ed. (CRC Press, Boca Raton, 2015), p. 371.

${ }^{43}$ X.-J. Chen et al., Proc. Natl. Acad. Sci. U. S. A. 102, 3198 (2005).

${ }^{44}$ A. Maxwell, S. Owen-Jones, and N. M. Jennett, Rev. Sci. Instrum. 75, 970 (2004).

${ }^{45}$ J. J. Worthman and R. A. Evans, J. Appl. Phys. 36, 153 (1965).

${ }^{46}$ A. C. Fischer-Cripps, Nanoindentation (Springer-Verlag, New York, 2011), pp. 1-19.

${ }^{47}$ S. Oktay, Z. Kahraman, M. Urgen, and K. Kazmanli, Appl. Surf. Sci. 328, 255 (2015).

${ }^{48}$ L. Kilpi, O. M. E. Ylivaara, A. Vaajoki, J. Malm, S. Sintonen, M. Tuominen, R. L. Puurunen, and H. Ronkainen, J. Vac. Sci. Technol., A 34, $01 \mathrm{~A} 124$ (2016).

${ }^{49}$ K. Holmberg, Finnish J. Tribol. 28, 16 (2009), available at https://journal. fi/tribologia/issue/view/3260/23.

${ }^{50} \mathrm{~K}$. Holmberg and A. Matthews, Coatings Tribology, 2nd ed. (Elsevier, Oxford, 2009), p. 54.

${ }^{51}$ J. Lyytinen et al., Wear 342-343, 270 (2015).

${ }^{52}$ A. Erdemir and J. M. Martin, Superlubricity (Elsevier, Amsterdam, 2007), pp. 253-294. 